Article

\title{
Co-Occurrence of Tetrodotoxin and Saxitoxins and Their Intra-Body Distribution in the Pufferfish Canthigaster valentini
}

\author{
Hongchen Zhu ${ }^{1}$, Takayuki Sonoyama ${ }^{2}$, Misako Yamada ${ }^{1}$, Wei Gao ${ }^{1}$, Ryohei Tatsuno ${ }^{3}$, \\ Tomohiro Takatani ${ }^{1}$ and Osamu Arakawa ${ }^{1, *(\mathbb{D})}$ \\ 1 Graduate School of Fisheries and Environmental Sciences, Nagasaki University. 1-14, Bunkyo-machi, \\ Nagasaki, Nagasaki 852-8521, Japan; zhc957286316@hotmail.com (H.Z.); tfg1akagumi@gmail.com (M.Y.); \\ gaowei0414@hotmail.com (W.G.); taka@nagasaki-u.ac.jp (T.T.) \\ 2 Shimonoseki Marine Science Museum. 6-1, Arcaport, Shimonoseki, Yamaguchi 750-0036, Japan; \\ sonoyama@kaikyokan.com \\ 3 Department of Food Science and Technology, National Fisheries University, Japan Fisheries Research and \\ Education Agency. 2-7-1, Nagatahonmachi, Shimonoseki, Yamaguchi 759-6595, Japan; tatsuno@fish-u.ac.jp \\ * Correspondence: arakawa@nagasaki-u.ac.jp; Tel.: +81-95-819-2844
}

Received: 9 June 2020; Accepted: 2 July 2020; Published: 3 July 2020

check for updates

\begin{abstract}
Pufferfish of the family Tetraodontidae possess tetrodotoxin (TTX) and/or saxitoxins (STXs), but the toxin ratio differs, depending on the genus or species. In the present study, to clarify the distribution profile of TTX and STXs in Tetraodontidae, we investigated the composition and intra-body distribution of the toxins in Canthigaster valentini. C. valentini specimens (four male and six female) were collected from Amami-Oshima Island, Kagoshima Prefecture, Japan, and the toxins were extracted from the muscle, liver, intestine, gallbladder, gonads, and skin. Analysis of the extracts for TTX by liquid chromatography tandem mass spectrometry and of STXs by high-performance liquid chromatography with post-column fluorescence derivatization revealed TTX, as well as a large amount of STXs, with neoSTX as the main component and dicarbamoylSTX and STX itself as minor components, in the skin and ovary. The toxins were also detected in the other tissues, but in much lower amounts than in the skin and ovary. The TTX/STX ratio varied greatly, depending on the tissue, but TTX was the major toxin component in the whole body, and STXs accounted for $25 \%$ and $13 \%$ of the total toxin amount in males and females, respectively. Like the marine pufferfish of the genus Arothron, C. valentini should be considered a pufferfish with considerable amounts of both TTX and STXs present simultaneously.
\end{abstract}

Keywords: tetrodotoxin (TTX); saxitoxin (STX); pufferfish; Canthigaster valentini

Key Contribution: Profile and intra-body distribution of tetrodotoxin and saxitoxins in the marine pufferfish of the family Tetraodontidae (Canthigaster valentini) were clarified.

\section{Introduction}

Pufferfish of the family Tetraodontidae are generally toxic, but the toxin profile differs, depending on the genus or species. Marine pufferfish of the genus Takifugu inhabiting the coastal waters of Japan possess the potent neurotoxin tetrodotoxin (TTX) as the major toxic component [1]. The liver and ovary, and, in some species, the skin, are strongly toxic [1,2] and the ingestion of these tissues often causes food poisoning. The muscle and testis, however, are nontoxic or weakly toxic and their consumption is thus permitted in Japan [3,4]. Although the regulatory limits for TTX consumption are not clearly defined in Japan, 10 mouse units (MU)/g tissue (equivalent to $2.2 \mu \mathrm{g}$ TTX/g or $6.9 \mathrm{nmol} \mathrm{TTX} / \mathrm{g}$ ) is 
generally used as the criterion for deciding whether or not the pufferfish tissue is edible; the European Food Safety Authority, however, claims that a concentration below $44 \mu \mathrm{g}$ TTX equivalents/kg shellfish meat, which is much lower than the Japanese criterion, does not result in adverse effects in humans [5]. TTX is an exogenous toxin for pufferfish, which ingest TTX-bearing benthic food organisms such as starfish, marine snails, and flatworms, and accumulate the toxin in specific organs [1]. The intra-body distribution of the toxins may change, depending on the growth and maturity of the individual [6-9].

However, small-sized freshwater pufferfish of the genera Pao and Leiodon (both formerly known as Tetraodon) living in Southeast Asian countries possess saxitoxins (STXs) instead of TTX as the main toxic component [10-13]. The skin and ovary are strongly toxic in these pufferfish, whereas the liver toxicity is relatively low. STXs comprise a group of neurotoxins involved in the toxification of bivalves, and the characteristics of the typical component STX are similar to those of TTX, including the molecular weight, toxicity, and intoxication mechanism [14]. Freshwater pufferfish do not live and are not eaten in Japan, but food poisoning, including fatal cases, due to the ingestion of these pufferfish occasionally occurs in Thailand, Bangladesh, and Cambodia [10-13]. The regulatory limit for STXs set by The Codex Committee on Fish and Fishery Products is $0.8 \mathrm{mg}$ STX·diHCl equivalents/kg tissue [15]. The accumulation mechanism of STXs in freshwater pufferfish is unclear, but it is presumed to be exogenous via the food chain originating from STX-producing cyanobacteria [12].

In general, freshwater pufferfish contain no TTX [10-13], whereas marine pufferfish not only contain TTX, but also occasionally contain STXs. Even in typical Takifugu marine pufferfish, such as Takifugu pardalis, Takifugu flavipterus, and Takifugu vermicularis, trace amounts of STXs may be detected in addition to the main toxin TTX [16-18]. Sato et al. [19] investigated the toxin profile of six marine pufferfish species of the genus Arothron and Chelonodon patoca collected in the Philippines, and reported that they all contain a large amount of STXs in addition to TTX. In particular, in four of the six Arothron species, STXs were the dominant toxin rather than TTX. Moreover, Nakashima et al. [20] investigated the toxin profile of Arothron firmamentum from Japanese coastal waters, and found that the skin contained only a small amount of TTX, whereas the ovary contained a large amount of toxin, mainly STXs. Therefore, the marine pufferfish of the genus Arothron has both TTX and STXs at the same time, with STXs often being the main component, making its toxin profile rather close to that of freshwater pufferfish of the genera Pao and Leiodon.

Canthigaster valentini is a small-sized marine pufferfish that lives on tropical and subtropical coral reefs and has a flashy appearance, with four clear, dark lateral zones on its spotted white body (Figure 1). In an interesting study relating to the appearance, Caley and Schluter [21] analyzed the response of predatory fish to plastic replicas of $C$. valentini (the model fish) and a general fish that looks similar to C. valentini (the mimic fish), and suggested that these model-mimic pairs avoid predation by being recognized as 'toxic fish' by the predatory fish. Although it is known that C. valentini is toxic [22], no information is available regarding the underlying source of its toxicity. Nakatani et al. [23] investigated the toxin profile of a pufferfish of the same genus, Canthigaster rivulata, using two individuals of an unknown sex, and detected a trace amount of STXs in addition to the major toxin TTX in the skin. On the other hand, Barrientos et al. [24] detected STXs, mainly comprising STX, with a tiny amount of TTX in Canthicaster rostrata, but the distribution of the toxins inside the body is unknown. In the present study, to clarify the distribution profile of TTX and STXs in pufferfish of the family Tetraodontidae, we investigated the composition and intra-body distribution of toxins in C. valentini. 

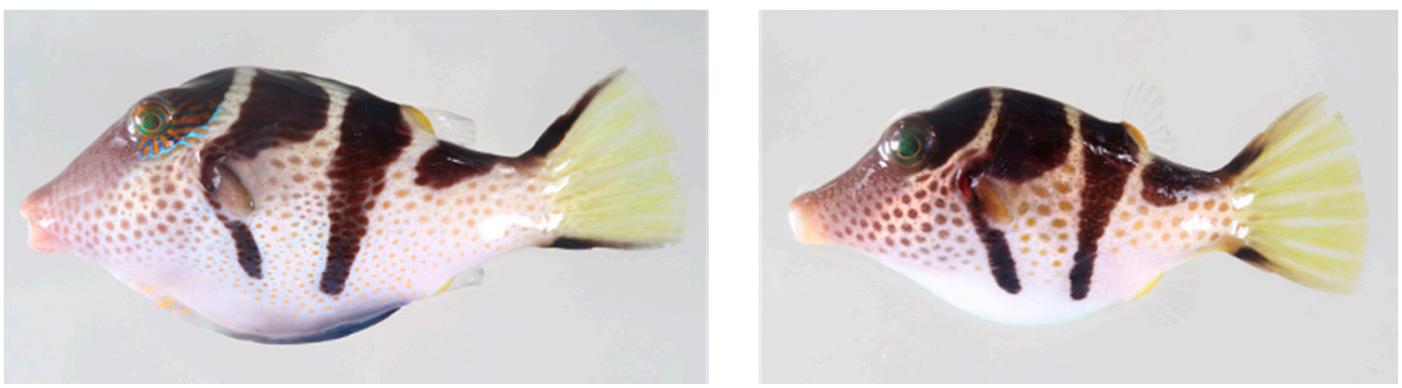

Figure 1. Male (left) and female (right) specimens of Canthigaster valentini. Males can be distinguished from females by the blue-green and orange lines that radiate posteriorly from both eyes, and a blue-gray patch anterior to the anus [25].

\section{Results}

Toxins were extracted from the muscle, liver, intestine, gallbladder, and gonads of four male and six female C. valentini specimens (Table 1) collected from Amami-Oshima Island in the Kagoshima Prefecture of Japan. Analysis of the extracts by liquid chromatography tandem mass spectrometry (LC-MS/MS) for TTX $[9,26]$ revealed that samples from all tissues produced a peak with a retention time corresponding to that of the TTX standard in the chromatogram monitored at $m / z 162$ as a product ion with $\mathrm{m} / \mathrm{z} 320$ as a precursor ion (described as $\mathrm{m} / \mathrm{z} 320>162$ hereafter; a typical chromatogram is shown in Figure 2). Although TTX analogues were not included in the analysis because no standards were available, peaks estimated to be 4-epiTTX, 4,9-anhydroTTX, 11-deoxyTTX, and 11-oxoTTX were observed at $m / z 320>162,302>162,304>162$, and $336>162$, respectively (typical chromatograms are shown in Figure A1). The peak intensities suggested that 4-epiTTX, 4,9-anhydroTTX, and 11-deoxyTTX were present in small amounts, while 11-oxoTTX was present at a higher level. When the same extracts were analyzed by high-performance liquid chromatography with post-column fluorescence derivatization (HPLC-FLD) for STXs [26,27], samples from each tissue, except for the female gallbladder, produced peaks at the retention times corresponding to those of neoSTX, decarbamoylSTX (dcSTX), and STX standards (a typical chromatogram is shown in Figure 3). No known components, such as C toxins and gonyautoxins (GTXs), were detected (data not shown). For the ovaries and skin of specimens No. 5 and 8, the sum of the MU conversion values calculated from the specific toxicity $[27,28]$ of each toxin component (i.e., TTX, neoSTX, dcSTX, and STX) and the toxicity value determined by the mouse bioassay [28] were compared. The two values were in agreement, or the mouse bioassay toxicity value was approximately $10 \%$ to $20 \%$ higher (Table 2), indicating that more than $80 \%$ of $C$. valentini's toxicity could be explained by TTX, neoSTX, dcSTX, and STX.

Table 1. Characteristics of C. valentini specimens.

\begin{tabular}{|c|c|c|c|c|}
\hline Sex & Specimen No. & Standard Body Length (mm) & Body Weight (g) & Gonadosomatic Index ${ }^{1}$ \\
\hline \multirow{5}{*}{$\sigma^{7}$} & 1 & 78.1 & 32.1 & 0.19 \\
\hline & 2 & 75.3 & 25.1 & 0.05 \\
\hline & 3 & 63.3 & 13.5 & 0.13 \\
\hline & 4 & 69.5 & 17.4 & 0.17 \\
\hline & Mean \pm SD & $71.8 \pm 6.8$ & $22.0 \pm 8.3$ & $0.13 \pm 0.06$ \\
\hline \multirow{7}{*}{ q } & 5 & 58.1 & 11.4 & 2.28 \\
\hline & 6 & 52.4 & 6.8 & 1.46 \\
\hline & 7 & 67.9 & 17.5 & 2.03 \\
\hline & 8 & 60.9 & 13.5 & 1.90 \\
\hline & 9 & 42.9 & 4.1 & 0.35 \\
\hline & 10 & 31.1 & 1.6 & 0.51 \\
\hline & Mean \pm SD & $52.2 \pm 13.3$ & $9.1 \pm 6.0$ & $1.4 \pm 0.8$ \\
\hline
\end{tabular}

${ }^{1}$ Gonadosomatic index (GSI), an indicator of maturity, was calculated from the gonad weight (GW) and body weight $(\mathrm{BW})$ using the following equation: GSI $=100 \times \mathrm{GW} / \mathrm{BW}[9]$. 


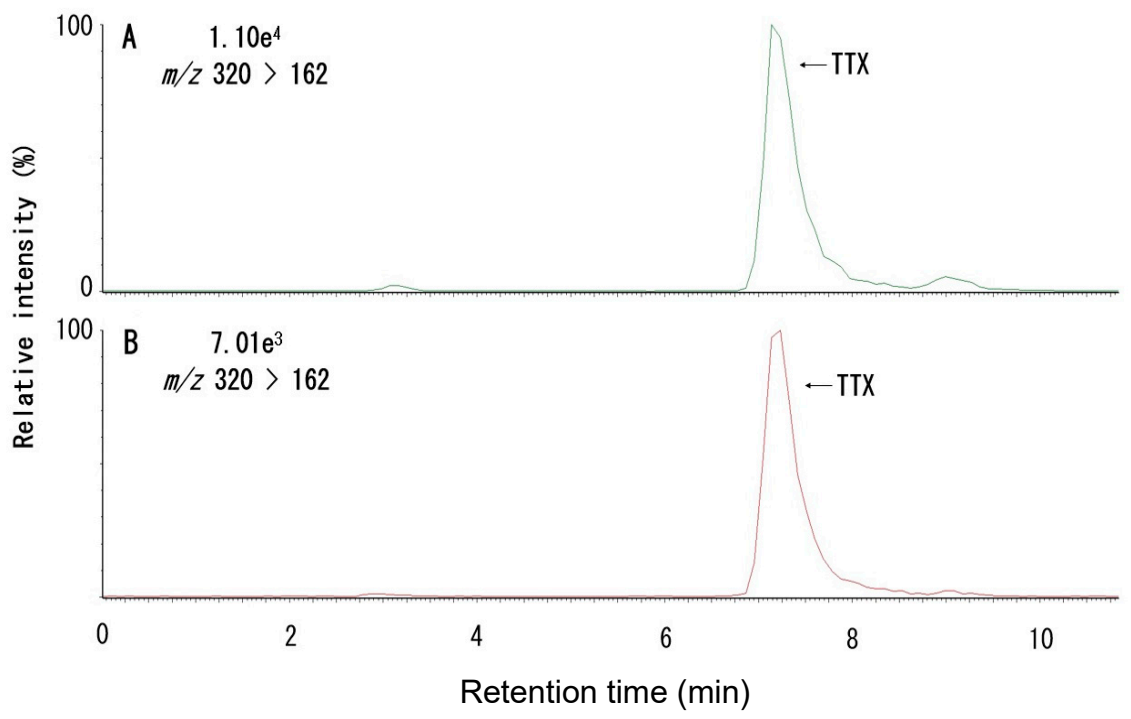

Figure 2. LC-MS/MS chromatograms of the ovary extract from specimen No. 5 (A) and of the tetrodotoxin (TTX) standard (B).
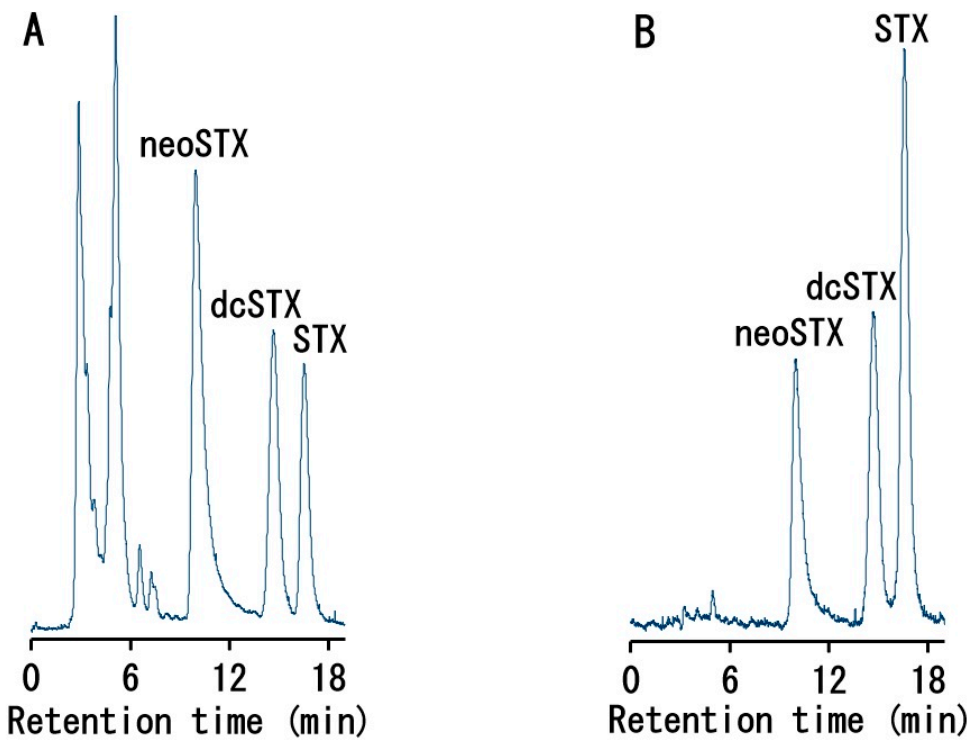

Figure 3. HPLC-FLD chromatograms of the ovary extract from specimen No. 5 (A) and of the neoSTX, decarbamoylSTX (dcSTX), and saxitoxin (STX) standards (B).

Table 2. Toxicity of the ovary and skin of specimens No. 5 and No. 8 determined by the mouse bioassay and instrumental analyses.

\begin{tabular}{ccccc}
\hline \multirow{2}{*}{ Method } & \multicolumn{4}{c}{ Toxicity (MU/g) } \\
\cline { 2 - 5 } & \multicolumn{2}{c}{ Specimen } & No. 5 & \multicolumn{2}{c}{ Specimen No. 8 } \\
\cline { 2 - 5 } & Ovary & Skin & Ovary & Skin \\
\hline Mouse Bioassay & 1094 & 720 & 1223 & 840 \\
Instrumental Analyses & 1100 & 702 & 1031 & 738 \\
\hline
\end{tabular}

The TTX/STX concentration in each tissue of male and female $C$. valentini specimens is shown in Figure 4, and Tables A1 and A2. The mean TTX concentration of each tissue was generally higher in females than in males. The mean TTX concentration was far higher in the ovary $(448 \mathrm{nmol} / \mathrm{g})$ and 
skin $(328 \mathrm{nmol} / \mathrm{g})$ in females and the skin $(123 \mathrm{nmol} / \mathrm{g})$ in males, and lower than $5 \mathrm{nmol} / \mathrm{g}$ in all of the other tissues, including the liver. On the other hand, the mean STX concentration (sum of neoSTX, dcSTX, and STX) in each tissue was similar for males and females, except for the gallbladder and gonads. Like TTX, the STX concentration was higher in the ovary $(65 \mathrm{nmol} / \mathrm{g})$ and skin $(30 \mathrm{nmol} / \mathrm{g})$ in females and the skin $(30 \mathrm{nmol} / \mathrm{g})$ in males, and less than $5 \mathrm{nmol} / \mathrm{g}$ in all of the other tissues except for the intestine (7-8 nmol/g in both sexes). No STXs were detected in the female gallbladder.
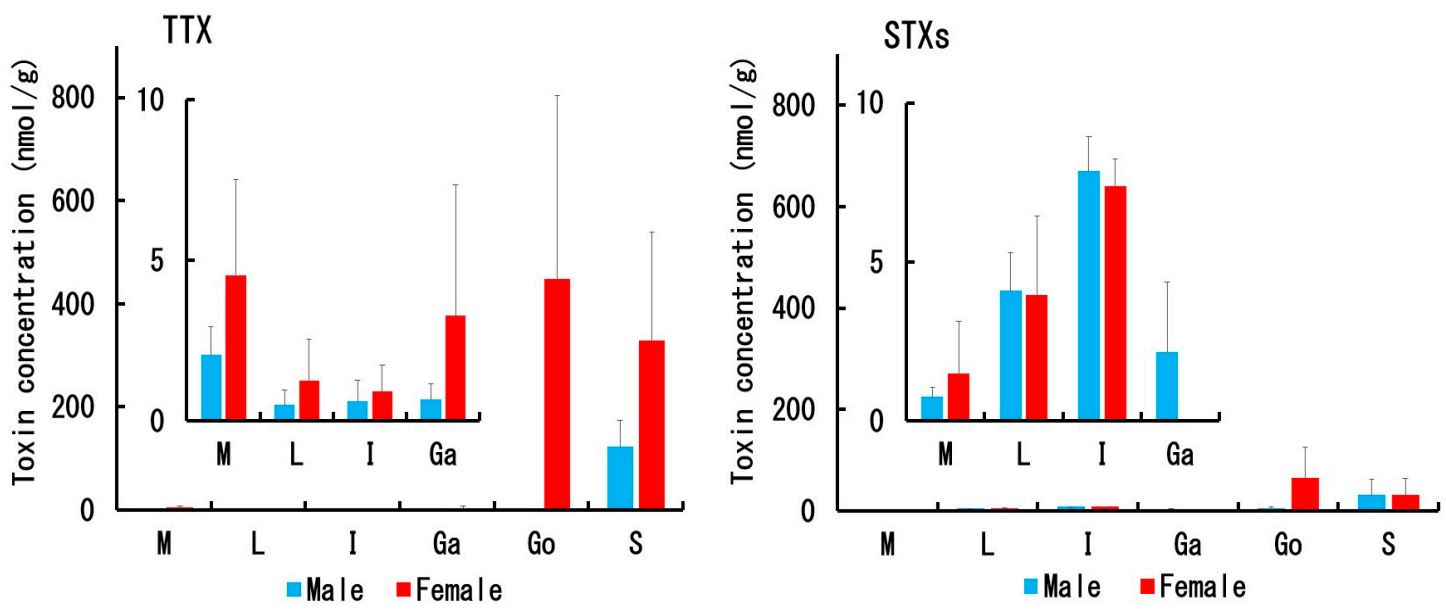

Figure 4. Concentration of TTX (left) and STXs (neoSTX + dcSTX + STX; right) in each tissue of male and female $C$. valentini specimens. Data are shown as the mean (columns) and SD (error bars). $\mathrm{M}=$ muscle, $\mathrm{L}=$ liver, $\mathrm{I}=$ intestine, $\mathrm{Ga}=$ gallbladder, $\mathrm{Go}=$ gonads, and $\mathrm{S}=$ skin.

The TTX/STX amount per individual retained in each tissue of male and female C. valentini specimens is shown in Figure 5. As described above, the TTX concentration in each tissue was higher in females than in males, but the mean total TTX amount per individual was about the same ( 630 nmol/individual) because the individual size of the males was larger than that of the females (Table 1). The skin accounted for most of the total TTX amount in both males and females, although females also had a considerable amount of TTX (76 nmol/individual) in the ovary. On the other hand, the mean total STX amount was higher in males (207 nmol/individual) than in females (93 nmol/individual), and like TTX, most of the toxin was contained in the skin in males, and in the skin and ovary in females.
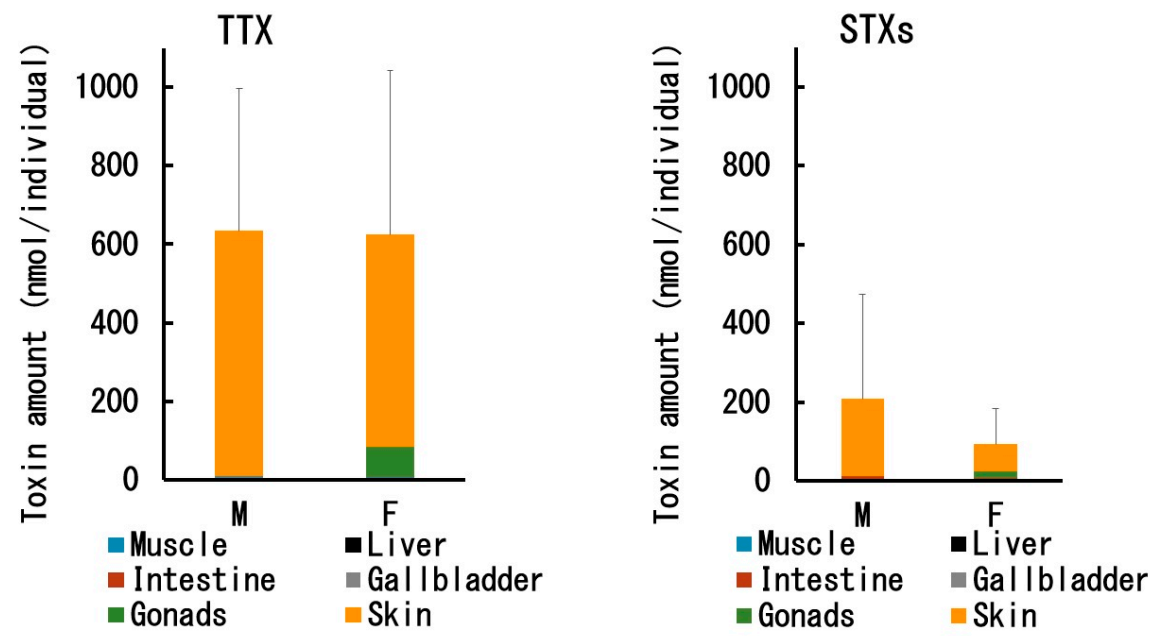

Figure 5. Amount of TTX (left) and STXs (neoSTX + dcSTX + STX; right) in each tissue of male (M) and female (F) C. valentini specimens. Data are shown as the mean (columns) and SD (error bars). 
The proportion of toxin components in each tissue of male and female $C$. valentini specimens is shown in Figure 6. The ratio of TTX and STXs (neoSTX + dcSTX + STX) in both males and females differed greatly, depending on the tissue. In males, TTX accounted for $\sim 75 \%$ of the total toxin amount in the muscle and skin, while STXs accounted for $\sim 90 \%$ in the other tissues. In females, as in males, TTX was the major component in the muscle and skin, and STXs were the major component in the liver and intestine. In strong contrast to males, TTX was the major component in the gallbladder and gonads in females. The STX composition also differed, depending on the tissue; in the skin and ovary, which accounted for most of the total toxin amount, neoSTX was the main component, and dcSTX and STX comprised the minor components, whereas in the other tissues, except for the female muscle, STX was the main component, and neoSTX and dcSTX were the minor components. In the whole body, the main toxin component of C. valentini was TTX in both males and females, but STXs, mainly neoSTX, comprised $25 \%$ of the toxin in males and $13 \%$ in females.
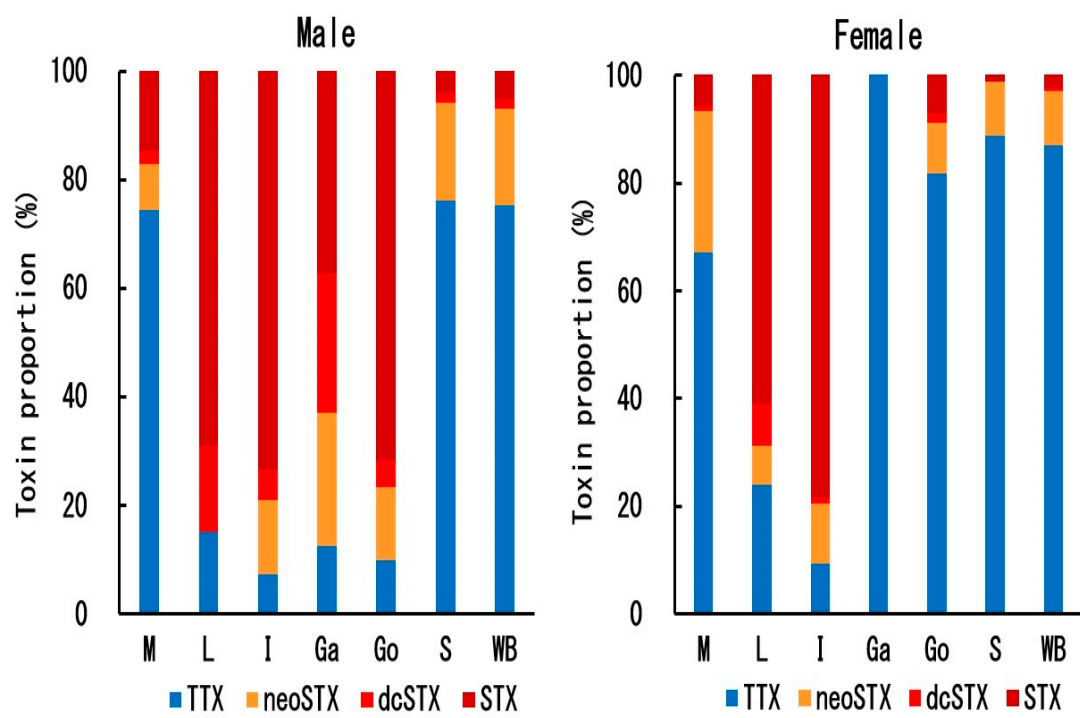

Figure 6. Proportion of each toxin component in each tissue of male (left) and female (right) C. valentini specimens. $\mathrm{M}=$ muscle, $\mathrm{L}=$ liver, $\mathrm{I}=$ intestine, $\mathrm{Ga}=$ gallbladder, $\mathrm{Go}=$ gonads, $\mathrm{S}=$ skin, and $\mathrm{WB}$ =whole body.

\section{Discussion}

The present study revealed that $C$. valentini inhabiting Amami-Oshima Island have a large amount of toxin in the skin and ovary. The major toxin component is TTX, but around $20 \%$ of the total toxin amount is accounted for by STXs, comprising neoSTX as the main component and dcSTX and STX as the minor components. Various TTX analogues, such as 4-epiTTX, 4,9-anhydroTTX, monodeoxyTTXs, dideoxyTTXs, trideoxyTTX, 11-norTTXs, and 11-oxoTTX, have been isolated from several marine pufferfish [29-32]. As 11-oxoTTX has a stronger toxicity than the other analogues [33,34] and is detected in pufferfish, marine snails, and crabs living in warm seas [33,35,36], its particular contribution to the toxicity of $C$. valentini has been considered to some extent, but as described above, it was excluded from analyses due to the lack of an available standard. On the other hand, an STX component undetectable by HPLC-FLD (carbamoyl- $N$-methyl derivative of STX) was isolated from Bangladeshi freshwater pufferfish [12,37]. Further studies are thus needed to clarify the existence/absence and detailed distribution of such TTX/STX analogues in C. valentini.

In C. valentini, the skin and ovary were the main toxin-accumulating tissues, and while the other tissues were also toxic, both the toxin concentration and toxin amount were minimal. Hwang et al. [22] examined the toxicity of Taiwanese specimens of $C$. valentini by a mouse bioassay, and reported that only the skin and ovary are toxic (10-200 MU/g). On the other hand, according to Nakatani et al. [23], 
the closely related species C. rivulata contains approximately $40 \mathrm{nmol} / \mathrm{g}(\sim 60 \mathrm{MU} / \mathrm{g}$ ) toxin (mainly TTX, along with a small amount of STXs) only in the skin. Therfore, in relation to the toxin distribution in the body, Canthigaster pufferfish, although they are a marine species, seem to be closer to freshwater pufferfish of the genera Pao and Leiodon, with a strong toxicity in the skin and ovary [10,13], than to marine pufferfish of the genus Takifugu, with a strong toxicity in the liver and ovary [1,2].

Marine Takifugu pufferfish with toxic skin have TTX secretory glands on the skin [38,39], and release TTX in response to external stimuli [40,41]. Itoi et al. [42] observed juveniles of generally nontoxic fish that ingest Takifugu pufferfish larvae and then promptly spit them out, and presumed that the TTX transferred from the mother acts to repel predators based on the findings that TTX primarily localized on the body surface of the larvae and that some general fish are able to sense extremely low levels of TTX with gustatory receptors [43]. Although it is currently being investigated whether C. valentini have toxin secretory glands on the skin, the extremely high toxicity of the skin strongly suggests that C. valentini also use the toxin as a repellent. Moreover, this finding strongly supports the hypothesis of Caley and Schluter [21] that C. valentini and their mimic fish avoid predation by being recognized as 'toxic fish' by predatory fish. Whether the predatory fish recognize STXs as well as TTX is an interesting issue for future study.

In C. valentini, the TTX/STX ratio varied greatly among the tissues; in the skin and ovary, which are the main toxin-accumulating tissues, most of the toxin was accounted for by TTX, whereas in the viscera, such as the liver, intestine, and testis, most of the toxin was accounted for by STXs. Among the six Arothron species from the Philippines, whose muscle, liver, intestine, and skin are all highly toxic, one species had a lower skin STX rate than the other tissues and one species had a higher liver STX rate than the other tissues, but the difference was not as extreme as that in C. valentini [19]. In the A. firmamentum specimens from Japanese coastal waters, in strong contrast to C. valentini, STXs accounted for most of the toxin in the ovary, which is the main toxin-accumulating tissue, and only a small amount of TTX was detected in the skin [20]. It is unclear why such a phenomenon occurs, but it may be that TTX/STXs are selectively taken up by the tissues. Nagashima et al. [44] used an in vitro tissue slice incubation method and found that unlike general marine fish, liver slices of Takifugu rubripes and marine pufferfish of the genus Lagocephalus remarkably take up TTX, but, like general marine fish, hardly take up STXs. The tissue slice incubation method can be applied to other tissues such as the skin and intestine [45], and we plan to use this method to examine the toxin uptake ability or toxin selectivity of each tissue of C. valentini.

The STXs harbored by $C$. valentini comprise neoSTX as the main component, and dcSTX and STX as the minor components. STXs harbored by pufferfish usually comprise STX as a main component, and neoSTX as a minor component $[10,11,13,16-20,24]$. Because STX is the main STX in the intestine, which absorbs the toxin into the body, and in the liver, which is the initial transfer site of the absorbed toxin $[7,46,47]$, it may be that the conversion of STX to neoSTX or selective uptake of neoSTX into the skin and ovary takes place inside the body of $C$. valentini. Further studies are needed to investigate this possibility, together with elucidation of the origin organisms of STXs.

In a recent in vivo TTX/STX administration experiment using nontoxic cultured individuals, Gao et al. [26] found that T. pardalis, which possesses TTX in nature, selectively accumulates TTX, and P. suvattii, which possesses STXs in nature, selectively accumulates STXs. In other words, the ratio of TTX/STX harbored by pufferfish is presumed to more strongly depend on the inherent TTX/STX selectivity of pufferfish than the prevalence of TTX/STX in prey organisms, but the molecular mechanisms remain to be elucidated. Yotsu-Yamashita et al. [48] isolated a soluble glycoprotein that binds to STX and TTX from the blood plasma of T. pardalis, and named it the pufferfish saxitoxin and tetrodotoxin binding protein (PSTBP). PSTBP homologous proteins are widely distributed in toxic pufferfish of the genera Takifugu and Arothron, but not found in nontoxic pufferfish species or general fish, and are suggested to be involved in the absorption, transportation, and accumulation of TTX in pufferfish [49-51]. On the other hand, an ongoing study indicates that freshwater pufferfish of the genus Pao do not have the PSTBP gene (Yamada et al., unpublished data). PSTBP also binds 
to STX [48], but may not be involved in STX accumulation or selectivity. Like the genus Arothron, the genus Canthigaster could be considered a pufferfish that can simultaneously possess TTX and STXs, but from the viewpoint of the TTX/STX ratio, Arothron and C. rostrata seem to be closer to $P a o$ and Leiodon, while C. rivulata and C. valentini seem to be closer to Takifugu marine pufferfish; that is, the STX accumulation ability could increase in the order of Takifugu, C. rivulata/C. valentini, Arothron/C. rostrata, and Pao/Leiodon. The presence or absence of PSTBP homologous proteins in the genus Canthigaster and the molecules involved in STX absorption, transportation, and accumulation instead of PSTBP are unknown, but by analyzing and comparing the molecular phylogeny of such toxin accumulation-related proteins with the TTX/STX distribution profile, it may be possible to estimate the evolutionary process in which the pufferfish acquired TTX/STXs. Studies along this line are ongoing.

\section{Materials and Methods}

\subsection{Pufferfish Specimens}

In April 2019, 10 specimens of C. valentini (Table 1) were collected at a coral reef off of Amami-Oshima Island in the Kagoshima Prefecture of Japan. They were transported live to the Shimonoseki Marine Science Museum, and after distinguishing males and females on the basis of the male-specific appearance, i.e., blue-green and orange lines that radiate posteriorly from both eyes, and a blue-gray patch anterior to the anus (Figure 1) [25], the muscle, liver, intestine, gallbladder, gonads, and skin were dissected out. The tissues were placed in individual plastic bags, frozen, and transported to the laboratory of Nagasaki University. They were stored below $-30{ }^{\circ} \mathrm{C}$ until toxin quantification.

\subsection{Toxin Quantification}

Each tissue of the $C$. valentini specimens was extracted with $0.1 \%$ acetic acid [28], passed through an HLC-DISK membrane filter ( $0.45 \mu \mathrm{m}$, Kanto Chemical Co., Inc., Tokyo, Japan), and subjected to LC-MS/MS for TTX [9,26] and HPLC-FLD for STXs [26,27].

In the LC-MS/MS analysis, chromatography was performed using an Alliance 2690 Separations Module (Waters, Milford, MA, USA) with a Mightysil RP-18 GP column $(2.0 \times 250 \mathrm{~mm}$, particle size $5 \mu \mathrm{m}$, Kanto Chemical Co., Inc.) and mobile phase comprising $30 \mathrm{mM}$ heptafluorobutyric acid in $1 \mathrm{mM}$ ammonium acetate buffer ( $\mathrm{pH} 5.0$ ) at a flow rate of $0.2 \mathrm{~mL} / \mathrm{min}$. The eluate was introduced into a Quattro microTM API detector (Waters) in which the TTX was ionized by positive-mode electrospray ionization with a desolvation temperature of $350^{\circ} \mathrm{C}$, a source block temperature of $120^{\circ} \mathrm{C}$, and a cone voltage of $50 \mathrm{~V}$, and monitored at $m / z 162$ (for quantitative analysis) and 302 (for qualitative analysis) as product ions (collision voltage $38 \mathrm{~V}$ ) with $\mathrm{m} / z 320$ as a precursor ion through a MassLynxTM NT operating system (Waters). Crystalline TTX (Nacalai Tesque, Inc., Kyoto, Japan) was used as an external standard. The limit of detection (LOD) and limit of quantification (LOQ) of TTX were $0.0009 \mathrm{nmol} / \mathrm{mL}$ $(S / N=3)$ and $0.003 \mathrm{nmol} / \mathrm{mL}(S / N=10)$, respectively.

HPLC-FLD was performed using Prominence Ultra-Fast Liquid Chromatography (Shimadzu, Kyoto, Japan) with an LiChroCART Superspher RP18 (e) column $(4.0 \times 250 \mathrm{~mm}$, particle size $4 \mu \mathrm{m}$, Kanto Chemical Co., Inc.). The toxins were separated using three mobile phases: a) $1 \mathrm{mM}$ tetrabutyl ammonium phosphate adjusted to $\mathrm{pH} 5.8$ with acetic acid for $\mathrm{C}$ toxins; b) $2 \mathrm{mM}$ heptanesulfonic acid in $10 \mathrm{mM}$ ammonium phosphate buffer ( $\mathrm{pH}$ 7.3) for GTXs; and c) $2 \mathrm{mM}$ heptanesulfonic acid in $4 \%$ acetonitrile-30 $\mathrm{mM}$ ammonium phosphate buffer ( $\mathrm{pH}$ 7.3) for neoSTX, dcSTX, and STX. The flow rate was $0.8 \mathrm{~mL} / \mathrm{min}$ and the column temperature was $35^{\circ} \mathrm{C}$. The elution from the column was mixed continuously with $50 \mathrm{mM}$ periodic acid and $0.2 \mathrm{M} \mathrm{KOH}$ containing $1 \mathrm{M}$ ammonium formate and $50 \%$ formamide and heated at $65^{\circ} \mathrm{C}$. The formation of fluorophores was monitored at $392 \mathrm{~nm}$ with $336 \mathrm{~nm}$ excitation. The reference materials of C1, C2, GTX1-4, and decarbamoylGTX2,3 were provided by the Japan Fisheries Research and Education Agency, and neoSTX, dcSTX, and STX purified from the toxic crab Zosimus aeneus [52] were used as external standards. The LOD and LOQ of STXs were $0.001-0.007 \mathrm{nmol} / \mathrm{mL}(S / N=3)$ and $0.003-0.02 \mathrm{nmol} / \mathrm{mL}(S / N=10)$, respectively. 
In both LC-MS/MS and HPLC-FLD analyses, the analytical range of the standard was up to 1 $\mathrm{nmol} / \mathrm{mL}$, and if the toxin concentration of the sample exceeded that range, the sample was re-analyzed after appropriate dilution.

For the ovaries and skin of specimens No. 5 and 8, the sum of the MU conversion values was calculated using the specific toxicity of each toxin component (TTX, $1.45 \mathrm{MU} / \mathrm{nmol}$; neoSTX, 2.30 MU/nmol; dcSTX, 1.27 MU/nmol; and STX, 2.48 MU/nmol) [27,28], and compared with the toxicity value determined by the mouse bioassay described below.

\subsection{Mouse Bioassay}

The ovary and skin extracts of the specimens No. 5 and 8 were examined for their toxicity by a mouse bioassay [28]. The lethal potency was expressed in MU, where $1 \mathrm{MU}$ was defined as the amount of toxin required to kill a 20-g male mouse of the ddY strain within 30 min after intraperitoneal administration. The experiment was performed according to the guidelines for the care and use of laboratory animals set by the Committee on Animal Experiments of Nagasaki University.

\subsection{Ethical Approval}

The mouse bioassay described above was approved by the Committee on Animal Experiments of Nagasaki University (Permission No. 1804021445) (date: 2 April 2018).

Author Contributions: Conceptualization, T.S., R.T., and O.A.; funding acquisition, O.A.; investigation, H.Z., M.Y., and T.T.; resources, T.S.; writing-original draft, H.Z. and W.G.; writing—review and editing, O.A. All authors have read and agreed to the published version of the manuscript.

Funding: This research was funded by the Japan Society for the Promotion of Science, $19 \mathrm{H} 03051$.

Conflicts of Interest: The authors declare no conflicts of interest.

\section{Appendix A}

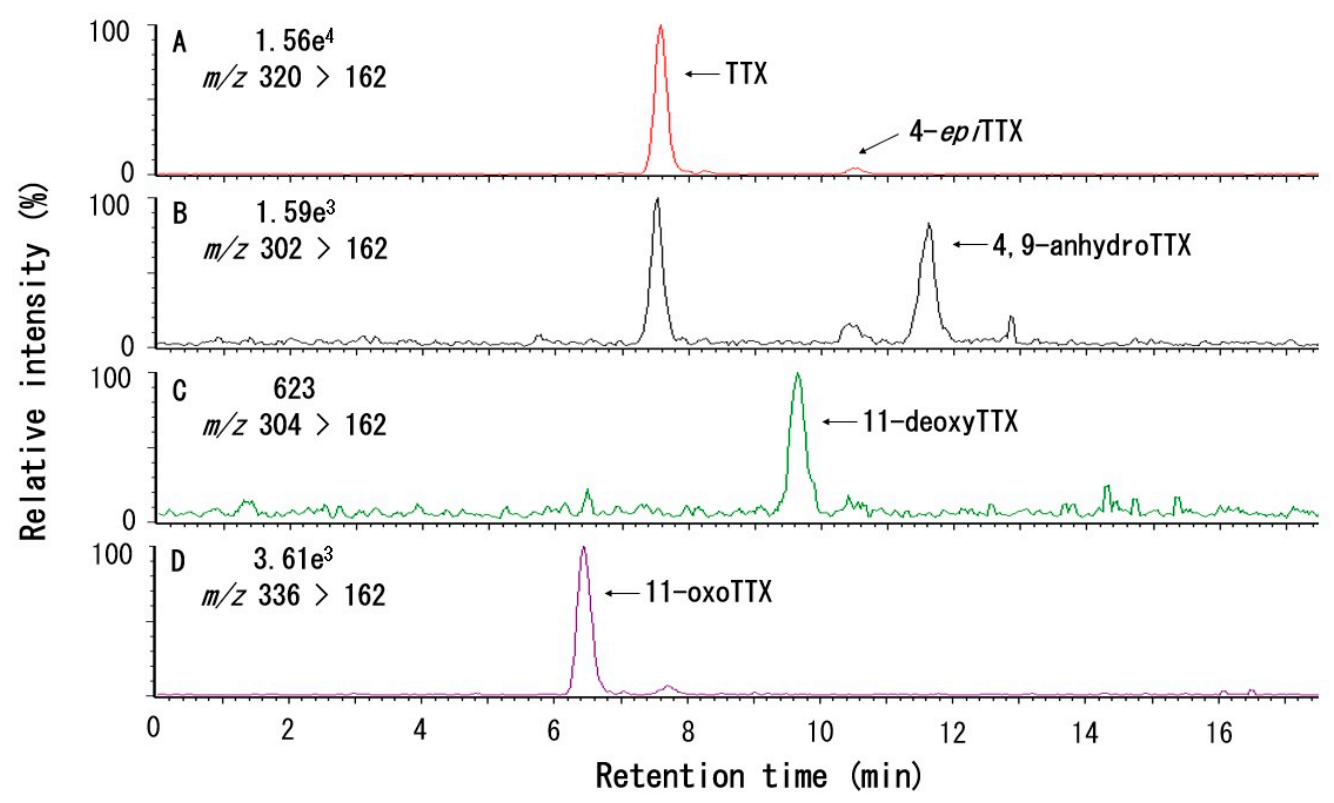

Figure A1. LC-MS/MS chromatograms at $m / z 320>162$ (A), $302>162$ (B), $304>162$ (C), and $336>162$ (D) of the ovary extract from specimen No. 5. 
Table A1. TTX concentration in each tissue.

\begin{tabular}{|c|c|c|c|c|c|c|c|}
\hline \multirow{2}{*}{ Sex } & \multirow{2}{*}{ Specimen No. } & \multicolumn{6}{|c|}{ TTX Concentration (nmol/g) } \\
\hline & & Muscle & Liver & Intestine & Gallbladder & Gonads & Skin \\
\hline \multirow{5}{*}{$0^{7}$} & 1 & 1.9 & 0.6 & 0.6 & 0.2 & 0.3 & 75 \\
\hline & 2 & 3.4 & 1.1 & 1.5 & 0.8 & 0.8 & 180 \\
\hline & 3 & 1.5 & 0.1 & 0.2 & 1.3 & 0.4 & 151 \\
\hline & 4 & 1.5 & 0.1 & 0.01 & 0.4 & 0.2 & 84 \\
\hline & Mean \pm SD & $2.0 \pm 0.9$ & $0.5 \pm 0.5$ & $0.6 \pm 0.7$ & $0.7 \pm 0.5$ & $0.4 \pm 0.3$ & $123 \pm 51$ \\
\hline \multirow{7}{*}{ q } & 5 & 4.0 & 3.5 & 2.0 & 0.8 & 648 & 420 \\
\hline & 6 & 2.4 & 0.2 & 0.2 & 1.8 & 165 & 108 \\
\hline & 7 & 3.1 & 0.3 & 0.4 & 1.2 & 414 & 239 \\
\hline & 8 & 4.3 & 0.6 & 0.7 & 1.2 & 455 & 361 \\
\hline & 9 & 3.0 & 0.6 & 0.2 & 2.9 & 1.1 & 157 \\
\hline & 10 & 10.4 & 2.1 & 1.9 & 11.5 & 1005 & 684 \\
\hline & Mean \pm SD & $4.5 \pm 3.0$ & $1.2 \pm 1.3$ & $0.9 \pm 0.8$ & $3.2 \pm 4.1$ & $448 \pm 355$ & $328 \pm 211$ \\
\hline
\end{tabular}

Table A2. STX (neoSTX + dcSTX + STX) concentration in each tissue.

\begin{tabular}{|c|c|c|c|c|c|c|c|}
\hline \multirow{2}{*}{ Sex } & \multirow{2}{*}{ Specimen No. } & \multicolumn{6}{|c|}{ STX Concentration (nmol/g) } \\
\hline & & Muscle & Liver & Intestine & Gallbladder ${ }^{1}$ & Gonads $^{2}$ & Skin \\
\hline \multirow{5}{*}{$\sigma^{7}$} & 1 & 1.0 & 5.5 & 8.8 & 5.3 & 1.2 & 78 \\
\hline & 2 & 0.3 & 3.6 & 8.5 & 1.9 & - & 11 \\
\hline & 3 & 0.9 & 4.6 & 7.7 & 1.4 & 9.5 & 10 \\
\hline & 4 & 0.8 & 2.6 & 6.3 & 0 & 1.5 & 21 \\
\hline & Mean \pm SD & $0.7 \pm 0.3$ & $4.1 \pm 1.2$ & $7.8 \pm 1.1$ & $2.1 \pm 2.2$ & $4.7 \pm 4.0$ & $30 \pm 33$ \\
\hline \multirow{7}{*}{ q } & 5 & 1.5 & 3.1 & 9.0 & 0 & 74 & 40 \\
\hline & 6 & 0.7 & 2.2 & 7.5 & 0 & 12 & 4 \\
\hline & 7 & 0.3 & 5.0 & 6.7 & 0 & 108 & 13 \\
\hline & 8 & 4.8 & 7.0 & 6.9 & 0 & 162 & 94 \\
\hline & 9 & 0.9 & 0.4 & 7.3 & 0 & 14 & 21 \\
\hline & 10 & 0.6 & 6.0 & 6.7 & 0 & 20 & 10 \\
\hline & Mean \pm SD & $1.5 \pm 1.7$ & $3.9 \pm 2.5$ & $7.4 \pm 0.8$ & 0 & $65 \pm 61$ & $30 \pm 34$ \\
\hline
\end{tabular}

${ }^{1} 0$ : less than the limit of quantification (LOQ), which was considered to be $0 .{ }^{2}$-: not examined because of a scarcity of tissue.

\section{References}

1. Noguchi, T.; Arakawa, O. Tetrodotoxin - distribution and accumulation in aquatic organisms, and cases of human intoxication. Mar. Drugs 2008, 6, 220-242. [CrossRef] [PubMed]

2. Tani, T. Nihonsan Fugu no Chudokugakuteki Kenkyu (Toxicological Studies on Japanese Puffer); Teikoku: Tosho, Tokyo, 1945.

3. Noguchi, T.; Ebesu, J.S.M. Puffer poisoning: Epidemiology and treatment. J. Toxicol. Toxin Rev. 2001, 20, 1-10. [CrossRef]

4. Toda, M.; Uneyama, C.; Toyofuku, H.; Morikawa, K. Trends of poisonings caused by natural toxins in Japan, 1989-2011. Food Hyg. Saf. Sci. 2012, 53, 105-120. [CrossRef]

5. EFSA Panel on Contaminants in the Food Chain. Risks for public health related to the presence of tetrodotoxin (TTX) and TTX analogues in marine bivalves and gastropods. EFSA J. 2017, 15, 4752.

6. Ikeda, K.; Emoto, Y.; Tatsuno, R.; Wang, J.J.; Ngy, L.; Taniyama, S.; Takatani, T.; Arakawa, O. Maturation-associated changes in toxicity of the pufferfish Takifugu poecilonotus. Toxicon 2010, 55, $289-297$.

[CrossRef]

7. Wang, J.; Araki, T.; Tatsuno, R.; Nina, S.; Ikeda, K.; Hamasaki, M.; Sakakura, Y.; Takatani, T.; Arakawa, O. Transfer profile of intramuscularly administered tetrodotoxin to artificial hybrid specimens of pufferfish, Takifugu rubripes and Takifugu niphobles. Toxicon 2011, 58, 565-569. [CrossRef] 
8. Tatsuno, R.; Shikina, M.; Shirai, Y.; Wang, J.; Soyano, K.; Nishihara, G.N.; Takatani, T.; Arakawa, O. Change in the transfer profile of orally administered tetrodotoxin to non-toxic cultured pufferfish Takifugu rubripes depending of its development stage. Toxicon 2013, 65, 76-80. [CrossRef]

9. Gao, W.; Kanahara, Y.; Tatsuno, R.; Soyano, K.; Nishihara, G.N.; Urata, C.; Takatani, T.; Arakawa, O. Maturation-associated changes in internal distribution and intra-ovarian microdistribution of tetrodotoxin in the pufferfish Takifugu pardalis. Fish. Sci. 2018, 84, 723-732. [CrossRef]

10. Kungsuwan, A.; Arakawa, O.; Promdet, M.; Onoue, Y. Occurrence of paralytic shellfish poisons in Thai freshwater puffers. Toxicon 1997, 35, 1341-1346. [CrossRef]

11. Sato, S.; Kodama, M.; Ogata, T.; Saitanu, K.; Furuya, M.; Hirayama, K.; Kamimura, K. Saxitoxin as a toxic principle of a freshwater puffer, Tetraodon fangi, in Thailand. Toxicon 1997, 35, 137-140. [CrossRef]

12. Zaman, L.; Arakawa, O.; Shimosu, A.; Onoue, Y. Occurrence of paralytic shellfish poison in Bangladeshi freshwater puffers. Toxicon 1997, 35, 423-431. [CrossRef]

13. Ngy, L.; Tada, K.; Yu, C.F.; Takatani, T.; Arakawa, O. Occurrence of paralytic shellfish toxins in Cambodian Mekong pufferfish Tetraodon turgidus: Selective toxin accumulation in the skin. Toxicon 2008, 51, 280-288. [CrossRef] [PubMed]

14. Cusick, K.D.; Sayler, G.S. An overview on the marine neurotoxin, saxitoxin: Genetics, molecular targets, methods of detection and ecological functions. Mar. Drugs 2013, 11, 991-1018. [CrossRef] [PubMed]

15. World Health Organization \& Food and Agriculture Organization of the United Nations. Toxicity Equivalence Factors for Marine Biotoxins Associated with Bivalve Molluscs; World Health Organization: Geneva, Switzerland, 2016.

16. Kodama, M.; Ogata, T.; Noguchi, T.; Maruyama, J.; Hashimoto, K. Occurrence of saxitoxin and other toxins in the liver of pufferfish Takifugu Pardalis. Toxicon 1983, 21, 897-900. [CrossRef]

17. Nakamura, M.; Oshima, Y.; Yasumoto, T. Occurrence of saxitoxin in puffer fish. Toxicon 1984, 22, $381-385$. [CrossRef]

18. Jang, J.; Yotsu-Yamashita, M. Distribution of tetrodotoxin, saxitoxin, and their analogs among tissues of the puffer fish Fugu pardalis. Toxicon 2006, 48, 980-987. [CrossRef]

19. Sato, S.; Ogata, T.; Borja, V.; Gonzales, C.; Fukuyo, Y.; Kodama, M. Frequent occurrence of paralytic shellfish poisoning toxins as dominant toxins in marine puffer from tropical water. Toxicon 2000, 38, 1101-1109. [CrossRef]

20. Nakashima, K.; Arakawa, O.; Taniyama, S.; Nonaka, M.; Takatani, T.; Yamamori, K.; Fuchi, Y.; Noguchi, T. Occurrence of saxitoxins as a major toxin in the ovary of a marine puffer Arothron firmamentum. Toxicon 2004, 43, 207-212. [CrossRef]

21. Caley, M.J.; Schluter, D. Predators favour mimicry in a tropical reef fish. Proc. R. Soc. Lond. B 2003, 270, 667-672. [CrossRef]

22. Hwang, D.F.; Kao, C.Y.; Yang, H.C.; Jeng, S.S.; Noguchi, T.; Hashimoto, K. Toxicity of puffer in Taiwan. Nippon Suisan Gakkaishi 1992, 58, 1541-1547. [CrossRef]

23. Nakatani, T.; Shimizu, M.; Yamano, T. The contents and composition of tetrodotoxin and paralytic shellfish poisoning toxins in marine pufferfish Canthigaster rivulata. J. Food Hyg. Soc. Japan 2016, 57, 51-56. [CrossRef]

24. Barrientos, R.G.; Hernández-Mora, G.; Alegre, F.; Field, T.; Flewelling, L.; McGrath, S.; Deeds, J.; Chacón, Y.S.; Arrieta, K.R.; Vargas, E.C.; et al. Saxitoxin poisoning in green turtles (Chelonia mydas) linked to scavenging on mass mortality of Caribbean sharpnose puffer fish (Canthigaster rostrata-Tetraodontidae). Front. Vet. Sci. 2019, 6, 466. [CrossRef] [PubMed]

25. Gladstone, W. Role of female territoriality in social and mating systems of Canthigaster valentini (Pisces: Tetraodontidae): Evidence from field experiments. Mar. Biol. 1987, 96, 185-191. [CrossRef]

26. Gao, W.; Kanahara, Y.; Yamada, M.; Tatsuno, R.; Yoshikawa, H.; Doi, H.; Takatani, T.; Arakawa, O. Contrasting toxin selectivity between the marine pufferfish Takifugu pardalis and the freshwater pufferfish Pao suvattii. Toxins 2019, 11, 470. [CrossRef]

27. Oshima, Y. Post-column devivatization HPLC method for analysis of PSP. J. AOAC Inter. 1995, 78, 528-532. [CrossRef]

28. Japan Food Hygiene Association. 1. Pufferfish toxin. In Standard Methods of Analysis in Food Safety Regulation; Japan Food Hygiene Association: Tokyo, Japan, 2015; pp. 813-820.

29. Yotsu-Yamashita, M. Chemistry of puffer fish toxin. J. Toxicol. Toxin Rev. 2001, 20, 51-66. [CrossRef]

30. Jang, J.H.; Yotsu-Yamashita, M. 6,11-Dideoxytetrodotoxin from the puffer fish, Fugu pardalis. Toxicon 2007, 50, 947-951. [CrossRef] [PubMed] 
31. Yotsu-Yamashita, M.; Abe, Y.; Kudo, Y.; Ritson-Williams, R.; Paul, V.J.; Konoki, K.; Cho, Y.; Adachi, M.; Imazu, T.; Nishikawa, T.; et al. First identification of 5,11-dideoxytetrodotoxin in marine animals, and characterization of major fragment ions of tetrodotoxin and its analogs by high resolution ESI-MS/MS. Mar. Drugs 2013, 11, 2799-2813. [CrossRef]

32. Kudo, Y.; Finn, J.; Fukushima, K.; Sakugawa, S.; Cho, Y.; Konoki, K.; Yotus-Yamashita, M. Isolation of 6-deoxytetrodotoxin from the pufferfish, Takifugu pardalis, and a comparison of the effects of the C-6 and C-11 hydroxy groups of tetrodotoxin on its activity. J. Nat. Prod. 2014, 77, 1000-1004. [CrossRef]

33. Khora, S.S.; Yasumoto, T. Isolation of 11-oxotetrodotoxin from the puffer Arothron nigropunctatus. Tetrahedron Lett. 1989, 30, 4393-4394. [CrossRef]

34. Wu, B.Q.; Yang, L.; Kao, C.Y.; Levinson, S.R.; Yotsu-Yamashita, M.; Yasumoto, T. 11-Oxo-tetrodotoxin and a specifically labeled ${ }^{3} \mathrm{H}$-tetrodotoxin. Toxicon 1996, 34, 407-416. [CrossRef]

35. Arakawa, O.; Noguchi, T.; Shida, Y.; Onoue, Y. Occurrence of 11-oxotetrodotoxin and 11-nortetrodotoxin-6(R)-ol in a xanthid crab Atergatis floridus collected at Kojima, Ishigaki Island. Fish. Sci. 1994, 60, 769-771. [CrossRef]

36. Taniyama, S.; Isami, Y.; Matsumoto, T.; Nagashima, Y.; Takatani, T.; Arakawa, O. Toxicity and toxin profile of tetrodotoxin detected in the scavenging gastropod Nassarius (Alectrion) glans "kinshibai". J. Food Hyg. Soc. Japan 2009, 50, 22-28. [CrossRef] [PubMed]

37. Zaman, L.; Arakawa, O.; Shimosu, A.; Shida, Y.; Onoue, Y. Occurrence of a methyl derivative of saxitoxin in Bangladeshi freshwater puffers. Toxicon 1998, 36, 627-630. [CrossRef]

38. Kodama, M.; Sato, S.; Ogata, T.; Suzuki, Y.; Kaneko, T.; Aida, K. Tetrodotoxin secreting glands in the skin of puffer fishes. Toxicon 1986, 24, 819-829. [CrossRef]

39. Mahmud, Y.; Okada, K.; Takatani, T.; Kawatsu, K.; Hamano, Y.; Arakawa, O.; Noguchi, T. Intra-tissue distribution of tetrodotoxin in two marine puffers Takifugu vermicularis and Chelonodon patoca. Toxicon 2003, 41, 13-18. [CrossRef]

40. Kodama, M.; Ogata, T.; Sato, S. External secretion of tetrodotoxin from puffer fishes stimulated by electric shock. Mar. Biol. 1985, 87, 199-203. [CrossRef]

41. Saito, T.; Noguchi, T.; Harada, T.; Murata, O.; Hashimoto, K. Tetrodotoxin as a biological defense agent for puffers. Bull. Jpn. Soc. Sci. Fish. 1985, 51, 1175-1180. [CrossRef]

42. Itoi, S.; Yoshikawa, S.; Asahina, K.; Suzuki, M.; Ishizuka, K.; Takimoto, N.; Mitsuoka, R.; Yokoyama, N.; Detake, A.; Takayanagi, C.; et al. Larval pufferfish protected by maternal tetrodotoxin. Toxicon 2014, 78, 35-40. [CrossRef]

43. Yamamori, K.; Nakamura, M.; Matsui, T.; Hara, T. Gustatory responses to tetrodotoxin and saxitoxin in fish: A possible mechanism for avoiding marine toxins. Can. J. Fish. Aqua. Sci. 1988, 45, 2182-2186. [CrossRef]

44. Nagashima, Y.; Ohta, A.; Yin, X.; Ishizaki, S.; Matsumoto, T.; Doi, H.; Ishibashi, T. Difference in uptake of tetrodotoxin and saxitoxins into liver tissue slices among pufferfish, boxfish and porcupinefish. Mar. Drugs 2018, 16, 17. [CrossRef] [PubMed]

45. Gao, W.; Yamada, M.; Ohki, R.; Nagashima, Y.; Tatsuno, R.; Ikeda, K.; Kawatsu, K.; Takatani, T.; Arakawa, O. Evaluation of the tetrodotoxin uptake ability of pufferfish Takifugu rubripes tissues according to age using an in vitro tissue slice incubation method. Toxicon 2020, 174, 8-12. [CrossRef] [PubMed]

46. Ikeda, K.; Murakami, Y.; Emoto, Y.; Ngy, L.; Taniyama, S.; Yagi, M.; Takatani, T.; Arakawa, O. Transfer profile of intramuscularly administered tetrodotoxin to non-toxic cultured specimens of the pufferfish Takifugu rubripes. Toxicon 2009, 53, 99-103. [CrossRef]

47. Wang, J.; Araki, T.; Tatsuno, R.; Nina, S.; Ikeda, K.; Takatani, T.; Arakawa, O. Transfer profile of orally and intramuscularly administered tetrodotoxin to artificial hybrid specimens of the pufferfish Takifugu rubripes and Takifugu porphyreus. Food Hyg. Saf. Sci. 2012, 55, 33-38. [CrossRef]

48. Yotsu-Yamashita, M.; Sugimoto, A.; Terakawa, T.; Shoji, Y.; Miyazawa, T.; Yasumoto, T. Purification, characterization, and cDNA cloning of a novel soluble saxitoxin and tetrodotoxin binding protein from plasma of the puffer fish, Fugu pardalis. Eur. J. Biochem. 2001, 268, 5937-5946. [CrossRef]

49. Yotsu-Yamashita, M.; Yamaki, H.; Okoshi, N.; Araki, N. Distribution of homologous proteins to puffer fish saxitoxin and tetrodotoxin binding protein in the plasma of puffer fish and among the tissues of Fugu pardalis examined by Western blot analysis. Toxicon 2010, 55, 1119-1124. [CrossRef] 
50. Tatsuno, R.; Yamaguchi, K.; Takatani, T.; Arakawa, O. RT-PCR- and MALDI-TOF mass spectrometry-based identification and discrimination of isoforms homologous to pufferfish saxitoxin- and tetrodotoxin-binding protein in the plasma of non-toxic cultured pufferfish (Takifugu rubripes). Biosci. Biotechnol. Biochem. 2013, 77, 208-212. [CrossRef]

51. Yotsu-Yamashita, M.; Nagaoka, Y.; Muramoto, K.; Cho, Y.; Konoki, K. Pufferfish saxitoxin and tetrodotoxin binding protein (PSTBP) analogues in the blood plasma of the pufferfish Arothron nigropunctatus, A. hispidus, A. manilensis, and Chelonodon patoca. Mar. Drugs 2018, 16, 224. [CrossRef]

52. Arakawa, O.; Noguchi, T.; Shida, Y.; Onoue, Y. Occurrence of carbamoyl-N-hydroxy derivatives of saxitoxin and neosaxitoxin in a xanthid crab Zosimus aeneus. Toxicon 1994, 32, 175-183. [CrossRef]

(C) 2020 by the authors. Licensee MDPI, Basel, Switzerland. This article is an open access article distributed under the terms and conditions of the Creative Commons Attribution (CC BY) license (http://creativecommons.org/licenses/by/4.0/). 